\section{Bio-behavioral survey of syphilis in homeless men in Central Brazil: a cross-sectional study}

\author{
Um inquérito bio-comportamental sobre sífilis \\ em homens sem-teto no Centro-oeste do Brasil: \\ um estudo transversal
}

\section{Cuestionario bioconductual sobre la sífilis en hombres sin techo en el Centro-oeste de Brasil: un estudio transversal}

\author{
Cleiciane Vieira de Lima Barros 1 \\ Hélio Galdino Júnior 1 \\ Giovanni Rezza 2 \\ Rafael Alves Guimarães 1 \\ Priscilla Martins Ferreira 1 \\ Christiane Moreira Souza 1 \\ Lara Cristina da Cunha Guimarães 1 \\ David Antônio Costa Barros 3 \\ Sandra Maria Brunini 1
}

\begin{abstract}
The objective of this study was to investigate the prevalence and factors associated with syphilis in homeless men in Central Brazil. It is a cross-sectional study conducted with 481 individuals attending four therapeutic communities between October and December 2015. A structured interview was conducted to collect sociodemographic data and risk factors for syphilis. Rapid/point-ofcare and VDRL tests were performed to determine exposure to syphilis and the presence of active syphilis, respectively. Poisson regression analysis was used to verify the risk factors associated with the outcomes investigated. Of the study participants, $10.2 \%$ were reactive to the rapid test, and $5.4 \%$ had active syphilis. At the multiple regression analysis, schooling (adjusted prevalence ratio - APR: 0.89; $p=0.005)$, history of genital ulcer (APR: 2.59; $p=$ 0.002), STI history (APR: 1.97; $p=0.042)$, and sexual intercourse under drug effects (APR: 1.60; $p=0.022$ ) were independent factors associated with lifetime syphilis. Also, history of genital ulcer (APR: 2.19; $p=0.019)$, STI history (APR: 1.74; $p=0.033$ ) and number of sexual partners in the last year (APR: 1.02; $p=0.044)$ were associated with active syphilis. The prevalence of syphilis among homeless men was rather high, confirming the vulnerability of this group to this infection. These results emphasize the need for educational intervention, improvement of risk reduction programs, availability of diagnostic tests, especially the rapid test, and treatment.
\end{abstract}

Syphilis; Homeless Persons; Risk Behavior

\author{
Correspondence \\ S. M. Brunini \\ Faculdade de Enfermagem, Universidade Federal de Goiás. \\ Rua 227, Quadra 68, Leste Universitário, Goiânia, \\ GO 74605-080, Brasil. \\ sandrabrunini@hotmail.com \\ 1 Faculdade de Enfermagem, Universidade Federal de Goiás, \\ Goiânia, Brasil. \\ 2 Istituto Superiore di Sanitá, Rome, Italy. \\ 3 Instituto Nacional de Cursos, Goiânia, Brasil.
}




\section{Background}

Syphilis is a major public health problem around the world. It is associated with several severe outcomes, including maternal-fetal complications, infertility, and death 1. This infection is highly endemic in developing countries, and in recent decades it has considerably reemerged in several developed countries. The World Health Organization 2 estimated about 36.4 million prevalent cases of syphilis and an incidence of 10.6 million infections every year, of which $90 \%$ are concentrated in low- and middle-income countries. In the Americas, it is estimated that 6.7 million people are infected with Treponema pallidum, and that 2.8 million new cases of syphilis occur per year 3 .

In particular, congenital syphilis is generally devastating worldwide, being associated with high morbidity and mortality 4 . In 2012, it was estimated that 350,000 adverse pregnancy outcomes were associated with syphilis, with 143,000 early fetal deaths/stillbirths, 62,000 neonatal deaths, 44,000 preterm/low birth weight babies and 102,000 infected infants 5. In the Region of the Americas, approximately 22,800 cases of congenital syphilis were estimated in 2015 in 37 countries and territories 6 . In Brazil, despite the advances in congenital syphilis policies and interventions, the epidemic has worsened, resulting in substantial fetal and neonatal mortality 7 . In 2015, 19,228 cases of congenital syphilis in children under one year of age were recorded in the Notifiable Diseases Information System (SINAN, acronym in Portuguese), resulting in an incidence rate of 5.4/1,000 live births. Also, the infant mortality rate for syphilis has increased from $2.4 / 100,000$ live births to $7.4 / 100,000$ live births from 2005 to 20158.

Syphilis has predominantly sexual transmission and less frequent parenteral and vertical transmission 9. Thus, this infection is predominant among individuals with high risk behaviors, such as alcohol and illicit drug use, injection drug use, inconsistent condom use, multiple sexual partners, and sex for money and/or drugs 10,11. In addition, investigations have shown that individuals with low income and education level and with difficulties of access to health services are more vulnerable to syphilis 12 . In this context, the infection is more common among certain key populations, such as individuals deprived of their liberty, illicit drug users, men who have sex with men, sex workers, and homeless persons 9 .

Homeless populations represent one of the groups that is most affected by epidemics of sexually transmitted infections (STIs) including syphilis 13,14,15. It is estimated that approximately 100 million people are homeless at the global level, and most are male ${ }^{16}$. Studies have shown a high frequency of risk behaviors among this population, such as consumption of psychoactive substances and inconsistent condom use 17,18,19,20. In addition, they are more susceptible to social and environmental risk factors related to STIs when compared with the general population ${ }^{13}$. The few studies conducted with homeless men have shown syphilis prevalence from $4.4 \%$ to $6.9 \% 10,21$.

In developing countries, such as Brazil, the real prevalence of syphilis in homeless men is still unknown. The only studies conducted in the country found prevalence ranging from 5.2 to $6.6 \%$ in this population 12,22. However, these studies included residents of only one city (São Paulo, Southeast region). In this context, epidemiological studies on infections such as syphilis in homeless men are important tools for the knowledge on this disease in this population, providing subsidies for the planning and implementation of measures of prevention, control, and treatment of the infection. This study aimed to investigate the prevalence and factors associated with syphilis in homeless men in Central Brazil.

\section{Methods}

A cross-sectional study was conducted using a non-probabilistic sample of homeless men between August and November 2015. Participants were recruited in four therapeutic communities for homeless people in the cities of Aparecida de Goiânia, Anápolis and Cocalzinho, located in the Goiás State, Central region of Brazil. We included all homeless men aged 18 or over who attended the institutions during the study period. Individuals with psychotic outbreak, severe mental illness or apparent psychomotor agitation were excluded from the study. No financial incentive was given for participation in this study. 
The sample needed to perform the study was 285 , considering a $80 \%$ statistical power $(\beta=20 \%$ ), 95\% significance level $(\alpha=0.05), 3.0$ design effect used to increase the sample and obtain a narrower $95 \%$ confidence interval (95\%CI) 23 , and $6.6 \% 12$ prevalence of active syphilis in homeless men. To achieve this value, $30 \%$ of eventual losses were added, totaling a minimum required sample of 370 homeless men.

Data were collected at the participating institutions by previously trained health professionals. After clarifying the objectives, methods, benefits and potential risks, all subjects who agreed to participate in the study answered a structured questionnaire about sociodemographic characteristics, psychoactive substance use, and risk factors for syphilis. The instrument was based on previously validated studies conducted on vulnerable populations and tested in a pilot study. After the interview, a digital puncture was performed for conducting the rapid/point-of-care test (treponemal test). Then, $5 \mathrm{~mL}$ of blood were collected through venipuncture, to perform the venereal diseases research laboraty (VDRL) test (non-treponemal test). All participants received pre-test counseling.

In this investigation, two dependent variables were considered: (i) exposure to syphilis, defined as positive in the rapid test 24 , and active syphilis, defined as positive in the rapid test and VRDL (any titre) 25. The following independents variables were considered: age (years); education level (years), length of stay on the street (days); marital status (married/consensual vs. single/separated/widowed), family cohabitation (yes vs. no); tattoo (yes vs. no); body piercing (yes vs. no); previous blood transfusion (yes vs. no); alcohol use (yes vs. no); marijuana use (yes vs. no); crack use (yes vs. no); use of intranasal cocaine (yes vs. no); injecting drug use (yes vs. no); previous HIV testing (yes vs. no); history of urethral discharge (yes vs. no); history of genital ulcer (yes vs. no); STIs history (yes vs. no); condom use (always vs. sometimes/never); condom use in the last sexual intercourse (yes vs. no); alcohol use before and/or during sexual intercourse (always vs. sometimes/never); use of illicit drugs before and/or during sexual intercourse (always vs. sometimes/never); sexual intercourse with STI carriers (yes vs. no); sex with sex workers (yes vs. no); sexual relations with illicit drug users (yes vs. no); homosexual sexual relation (yes vs. no) and number of sexual partners. The consumption of psychoactive substances was measured for the last 30 days, except for injection drugs which were measured for the participant's lifetime. Sexual behavior information was restricted to the last year.

The data were analyzed using the statistical program Stata (StataCorp LP, College Station, USA) version 12.0. Initially, the quantitative variables were verified through the Anderson-Darling test 26. Descriptive analysis of the variables was performed. The quantitative variables were presented as median and interquartile range (IQR) and the qualitative variables, as absolute and relative frequencies. Lifetime and active syphilis prevalence was estimated with 95\%CI. Poisson regression with robust variance estimation 27,28 was used to analyze the independent contribution of each risk factor to the investigated outcomes. In the multivariable analysis, the inclusion criterion adopted was p-value $<0.20$ in the bivariate analysis for potential confounders, and the variables which had significance lower than 0.05 remained in the final model. The multivariable analysis results are presented as adjusted prevalence ratio (APR) and with a respective $95 \%$ CI. Variables with values of $\mathrm{p}<0.05$ were considered statistically significant.

\section{Ethical aspects}

This study was approved by the Ethics Committee of the Federal University of Goiás' University Hospital, under number 1236774. Consent was obtained from all participants. The results of the rapid test were delivered to the participants, immediately after the post-test counseling. Next, they were referred to the health unit closest to the interview site for clinical follow-up and treatment.

\section{Results}

\section{Characteristics of the participants}

Of the total number of potentially eligible participants attending the institutions during the study period $(\mathrm{n}=511), 481$ agreed to participate $(94.1 \%$ response rate). Table 1 summarizes the 
Table 1

Sociodemographic characteristics, substance use, and risk behaviors of homeless men in Central Brazil.

\begin{tabular}{|c|c|c|}
\hline Variables & $n$ * & $\%$ \\
\hline Age (years) & \multicolumn{2}{|c|}{$36(29.0-45.0)$} \\
\hline Education (years) ** & \multicolumn{2}{|c|}{$8.0(6.0-11.0)$} \\
\hline Time spent on the streets (days) & \multicolumn{2}{|c|}{$90.0(7.0-1,095.0)$} \\
\hline \multicolumn{3}{|l|}{ Marital status *** } \\
\hline Married/Consensual union & 65 & 13.7 \\
\hline Single/Separated/Widowed & 411 & 86.3 \\
\hline \multicolumn{3}{|l|}{ Children ** } \\
\hline No & 161 & 33.6 \\
\hline Yes & 318 & 66.4 \\
\hline \multicolumn{3}{|l|}{ Living family $* * *$} \\
\hline Yes & 318 & 66.8 \\
\hline No & 158 & 33.2 \\
\hline \multicolumn{3}{|l|}{ Previous hospitalization $* \star *$} \\
\hline No & 151 & 31.5 \\
\hline Yes & 328 & 68.5 \\
\hline \multicolumn{3}{|l|}{ Previous imprisonment } \\
\hline No & 144 & 29.9 \\
\hline Yes & 337 & 70.1 \\
\hline \multicolumn{3}{|l|}{ Tattoo \# } \\
\hline No & 269 & 56.0 \\
\hline Yes & 211 & 44.0 \\
\hline \multicolumn{3}{|l|}{ Body piercing } \\
\hline No & 359 & 74.6 \\
\hline Yes & 122 & 25.4 \\
\hline \multicolumn{3}{|l|}{ Previous hemotransfusion \# } \\
\hline No & 408 & 85.0 \\
\hline Yes & 72 & 15.0 \\
\hline \multicolumn{3}{|l|}{ Use of psychoactive substances \#\# } \\
\hline Alcohol & 358 & 74.9 \\
\hline Marijuana & 181 & 37.9 \\
\hline Crack & 254 & 53.1 \\
\hline Cocaine & 182 & 38.1 \\
\hline Other substance & 85 & 17.8 \\
\hline \multicolumn{3}{|l|}{ Injection drug use } \\
\hline No & 439 & 91.3 \\
\hline Yes & 42 & 8.7 \\
\hline \multicolumn{3}{|l|}{ HIV testing } \\
\hline No & 401 & 83.4 \\
\hline Yes & 80 & 16.6 \\
\hline \multicolumn{3}{|l|}{ STI history \#\#\# } \\
\hline No & 314 & 66.1 \\
\hline Yes & 161 & 33.9 \\
\hline \multicolumn{3}{|l|}{ History of urethral discharge \#\#\# } \\
\hline No & 337 & 70.9 \\
\hline Yes & 138 & 29.1 \\
\hline \multicolumn{3}{|l|}{ History of genital ulcer } \\
\hline No & 407 & 84.6 \\
\hline Yes & 74 & 15.4 \\
\hline
\end{tabular}

(continues) 
Table 1 (continued)

\begin{tabular}{|c|c|c|}
\hline Variables & $n$ * & $\%$ \\
\hline \multicolumn{3}{|l|}{ Condom use § } \\
\hline Always & 82 & 17.4 \\
\hline Sometimes/Never & 390 & 82.6 \\
\hline \multicolumn{3}{|l|}{ Condom use in the last sexual intercourse ** } \\
\hline No & 199 & 42.4 \\
\hline Yes & 270 & 57.6 \\
\hline \multicolumn{3}{|l|}{ Alcohol use before or during intercourse \# } \\
\hline Always & 51 & 10.6 \\
\hline Sometimes/Never & 429 & 89.4 \\
\hline \multicolumn{3}{|l|}{ Drug use before or during intercourse \#\# } \\
\hline Always & 190 & 39.7 \\
\hline Sometimes/Never & 288 & 60.3 \\
\hline \multicolumn{3}{|l|}{ Sexual intercourse with illicit drug users \#\#\# } \\
\hline No & 133 & 28.0 \\
\hline Yes & 342 & 72.0 \\
\hline \multicolumn{3}{|l|}{ Sexual intercouse with sex workers \# } \\
\hline No & 137 & 28.5 \\
\hline Yes & 343 & 71.5 \\
\hline \multicolumn{3}{|l|}{ Homosexual sexual intercourse \# } \\
\hline No & 336 & 70.0 \\
\hline Yes & 144 & 30.0 \\
\hline \multicolumn{3}{|l|}{ Sexual intercourse with people with STI *** } \\
\hline No & 397 & 83.4 \\
\hline Yes & 79 & 16.6 \\
\hline Number of sexual partners in the last year $\star \star \star *$ & \multicolumn{2}{|c|}{$2.0(1.0-5.0)$} \\
\hline
\end{tabular}

STI: sexually transmitted infection.

Note: quantitative variables presented as median and interquartile range (IQR).

$*^{\mathrm{n}}=481$;

** Missing $=12$;

*** Missing $=5$;

\# Missing $=1$;

\#\# Missing = 3;

\#\#\# Missing = 6;

$\S$ Missing $=9$.

sociodemographic characteristics, use of psychoactive substances, and risk behaviors reported by the study participants. The median age, education level and time spent homeless was 36 years (IQR: 29-45), eight years (IQR: 6-11), and 90 days (IQR: 7.0-1,095.0), respectively. Most of them were single/ separated/widowed (86.3\%) and had children (66.4\%).

Lifetime use of psychoactive substances was reported by $97.7 \%$ of the homeless men. The participants reported consumption of alcohol (74.9\%), marijuana (37.9\%), crack (53.1\%), intranasal cocaine (38.1\%), and other substances (17.8\%) in the previous 30 days. Overall, $8.7 \%$ of the participants reported injecting drug use; of them, $42.9 \%$ reported a history of sharing of drug use instruments. The median onset of drug use was 15 years (IQR: 13-18) (Table 1).

Antecedents of urethral discharge and genital ulcer were reported by $29.1 \%$ and $15.4 \%$ of the participants, respectively. STIs history was reported by $33.9 \%$ of the sample. Only $16.6 \%$ of the men reported previous HIV testing. Inconsistent condom use (sometimes/never) was reported by most participants (82.6\%). Of the total, $89.4 \%$ and $60.3 \%$ reported use of alcohol and illicit drugs before and/ or during sexual intercourse, respectively. In addition, $72 \%$ reported having had sex with illicit drug users; $71.5 \%$ with sex workers; $30 \%$ with people of the same sex; $16.6 \%$ with STI carriers. The median number of sexual partners in the last year was two (IQR: 1.0-5.0) (Table 1). 


\section{Syphilis prevalence}

Overall, 49 men (10.2\%; 95\%CI: 7.8-13.2) were reactive to the rapid test, suggesting current or past infection (exposure to syphilis). Of these, 26 exhibited positive VDRL, resulting in a $5.4 \%$ prevalence of active syphilis (95\%CI: $3.7-7.8)$.

\section{Factors associated with syphilis}

Table 2 shows the factors associated with exposure to and active syphilis in the bivariate Poisson analysis. History of genital ulcer $(\mathrm{p}=0.010)$, and STIs history $(\mathrm{p}=0.001)$ were predictors of exposure to syphilis in this analysis. Also, alcohol use $(\mathrm{p}=0.016)$, crack use $(\mathrm{p}=0.046)$, history of genital ulcer $(\mathrm{p}=0.010)$ and STIs history $(\mathrm{p}=0.008)$ were factors associated with active syphilis in this analysis.

Table 3 presents the results of the multiple regression model of factors associated with exposure to syphilis. Education level (APR: 0.89; $\mathrm{p}=0.005$ ), history of genital ulcer (APR: $2.59 ; \mathrm{p}=0.002$ ), STIs history (APR: 1.97; $\mathrm{p}=0.042$ ), and use of illicit drugs before and/or during sexual intercourse (APR: $1.60 ; \mathrm{p}=0.022$ ) were independent factors associated with this outcome. Table 4 presents the results of the multiple regression model of factors associated with active syphilis. The following factors were predictors of active syphilis: history of genital ulcer (APR: 2.19; $\mathrm{p}=0.019$ ), STIs history (APR: 1.74; $\mathrm{p}=0.033$ ), and number of sexual partners in the last year (APR: 1.02; $\mathrm{p}=0.044)$.

\section{Discussion}

This study investigated the prevalence and factors associated with syphilis in homeless men in Central Brazil. Consistently with existing literature 10,22,29, the results of this research show high rates of risk behavior, including use of alcohol and/or illicit drugs, multiple sexual partners, inconsistent use of condoms, sexual practices under the influence of alcohol, and/or illicit drugs, and with groups (illicit drug users, sex workers and STI carriers). In addition, a high prevalence of syphilis was observed in the study population, and an association was found with important predictors (low education level, number of sexual partners, sexual intercourse under illicit drug use, history of STI, and genital ulcer). These results suggest a high vulnerability of homeless men to syphilis in Brazil, and the potential risk of acquiring other STIs, including infection by HIV.

The prevalence of active syphilis found in this study (5.4\%; 95\%CI: 3.7-7.8) was higher than that reported in industrial workers (1.9\%; 95\%CI: 1.5-2.5) 30, and Brazilian conscripts $(0.5 \%$; 95\%CI: $0.45-0.61) 31$, confirming the vulnerability of homeless men to this infection. These rateswere similar to those found in studies conducted with homeless men in the city of São Paulo. Brito et al. 22 estimated 5.2\% prevalence (95\%CI: 3.1- 8.6) among 267 individuals recruited at night shelters. Pinto et al. 12 found a $6.6 \%$ frequency of active syphilis (95\%CI: 5.3-8.2) among 1,194 men assisted in social support services.

In the multivariable analysis, low education level, sexual intercourse under effects of illicit drugs and history of genital ulcer and STIs history were variables associated with exposure to syphilis. Moreover, history of genital ulcer, STIs history, and number of sexual partners were predictors of active syphilis. These factors have also been associated with syphilis in studies previously conducted with vulnerable populations in Brazil and in other countries 12,32,33.

In this study, the prevalence of exposure to syphilis decreased by $11 \%$ for each year of formal education. In fact, structural factors (e.g., low income and educaton level) are related to the increased risk acquisition of STIs in several key populations, including homeless men 34,35. Some evidence suggests that low education level, used as a proximal socioeconomic variable, is associated with higher prevalence of certain STIs, involvement in high-risk behaviors (e.g., inconsistent condom use), low level of knowledge on preventive methods and access to health services and protection 36,37 , which explains the relationship between this factor and infection by T. pallidum.

Our results show a high frequency of sexual intercourse under effects of illicit drugs in the study sample (60.3\%), which is associated with exposure to syphilis. Also, many participants reported the use of substances such as crack, cocaine, and marijuana, and three-quarters of the men reported 
Table 2

Bivariate analysis of factors associated with lifetime and active syphilis in homeless men in Central Brazil.

\begin{tabular}{|c|c|c|c|c|c|c|c|c|}
\hline \multirow[t]{2}{*}{ Variables } & \multicolumn{4}{|c|}{ Lifetime syphilis } & \multicolumn{4}{|c|}{ Active syphilis } \\
\hline & Positive & $\%$ & PR $(95 \% \mathrm{Cl})$ & p-value * & Positive & $\%$ & PR $(95 \% \mathrm{Cl})$ & p-value * \\
\hline Age (years) & $39.0(3$ & 44.0) & $1.01(0.99-1.04)$ & 0.203 & $35.0(2$ & 45.0) & $0.99(0.95-1.0)$ & 0.604 \\
\hline Education (years) & $9.0(6$ & 1.0) & $0.93(0.86-1.01)$ & 0.106 & $9.0(7$. & $0.0)$ & $1.07(0.96-1.2)$ & 0.205 \\
\hline Time spent on the streets (days) & $90.0(7$ & 30.0) & $1.01(0.99-1.04)$ & 0.198 & $90.0(37$. & 098.7) & $1.02(0.99-1.1) * * *$ & 0.169 \\
\hline \multicolumn{9}{|l|}{ Marital status } \\
\hline Married/Consensual union & 8 & 12.3 & 1.00 & & 5 & 7.7 & 1.00 & \\
\hline Single/Separated/Widowed & 41 & 10.0 & $0.81(0.38-1.72)$ & 0.587 & 21 & 5.1 & $0.66(0.3-1.87)$ & 0.417 \\
\hline \multicolumn{9}{|l|}{ Living family } \\
\hline Yes & 33 & 10.4 & 1.00 & & 20 & 6.3 & 1.00 & \\
\hline No & 16 & 10.1 & $0.97(0.53-1.77)$ & 0.936 & 6 & 3.8 & $0.60(0.2-1.5)$ & 0.281 \\
\hline \multicolumn{9}{|l|}{ Tattoo } \\
\hline No & 24 & 8.9 & 1.00 & & 12 & 4.5 & 1.00 & \\
\hline Yes & 25 & 11.8 & $1.34(0.76-2.34)$ & 0.305 & 14 & 6.7 & $1.50(0.69-3.24)$ & 0.301 \\
\hline \multicolumn{9}{|l|}{ Body piercing } \\
\hline No & 37 & 10.3 & 1.00 & & 19 & 5.3 & 1.00 & \\
\hline Yes & 12 & 9.8 & $0.95(0.50-1.84)$ & 0.901 & 7 & 5.8 & $1.09(0.45-2.59)$ & 0.845 \\
\hline \multicolumn{9}{|l|}{ Previous hemotransfusion } \\
\hline No & 38 & 9.4 & 1.00 & & 20 & 4.9 & 1.00 & \\
\hline Yes & 11 & 15.3 & $1.63(0.83-3.19)$ & 0.152 & 6 & 8.3 & $1.69(0.67-4.21)$ & 0.259 \\
\hline \multicolumn{9}{|l|}{ Alcohol use } \\
\hline No & 17 & 14.3 & 1.00 & & 12 & 10.1 & 1.00 & \\
\hline Yes & 32 & 8.9 & $0.62(0.34-1.12)$ & 0.120 & 14 & 3.9 & $0.38(0.17-0.84)$ & 0.016 \\
\hline \multicolumn{9}{|l|}{ Marijuana use } \\
\hline No & 31 & 10.4 & 1.00 & & 17 & 5.7 & 1.00 & \\
\hline Yes & 18 & 9.9 & $0.95(0.53-1.70)$ & 0.876 & 9 & 5.0 & $0.87(0.38-1.95)$ & 0.737 \\
\hline \multicolumn{9}{|l|}{ Crack use } \\
\hline No & 20 & 8.9 & 1.00 & & 7 & 3.1 & 1.00 & \\
\hline Yes & 29 & 11.4 & $1.28(0.72-2.27)$ & 0.383 & 19 & 7.5 & $2.41(1.01-5.73)$ & 0.046 \\
\hline \multicolumn{9}{|l|}{ Cocaine use } \\
\hline No & 30 & 10.1 & 1.00 & & 13 & 4.4 & 1.00 & \\
\hline Yes & 19 & 10.4 & $1.03(0.58-1.83)$ & 0.914 & 13 & 7.7 & $1.62(0.75-3.51)$ & 0.213 \\
\hline \multicolumn{9}{|l|}{ Injection drug use } \\
\hline No & 46 & 10.5 & 1.00 & & 23 & 5.3 & 1.00 & \\
\hline Yes & 3 & 7.1 & $0.67(0.21-2.28)$ & 0.515 & 3 & 7.1 & $1.35(0.40-4.51)$ & 0.619 \\
\hline \multicolumn{9}{|l|}{ HIV testing } \\
\hline No & 39 & 9.7 & 1.00 & & 21 & 5.3 & 1.00 & \\
\hline Yes & 10 & 12.5 & $1.27(0.63-2.56)$ & 0.488 & 5 & 6.3 & $1.18(0.44-3.14)$ & 0.730 \\
\hline \multicolumn{9}{|l|}{ History of urethral discharge } \\
\hline No & 31 & 9.2 & 1.00 & & 19 & 5.6 & 1.00 & \\
\hline Yes & 18 & 13.0 & $0.89(0.37-2.14)$ & 0.811 & 7 & 5.1 & $0.89(0.37-2.14)$ & 0.811 \\
\hline \multicolumn{9}{|l|}{ History of genital ulcer } \\
\hline No & 33 & 8.1 & 1.00 & & 17 & 4.2 & 1.00 & \\
\hline Yes & 16 & 21.6 & $2.91(1.29-6.53)$ & 0.010 & 9 & 12.2 & $2.91(1.29-6.53)$ & 0.010 \\
\hline \multicolumn{9}{|l|}{ STI history } \\
\hline No & 20 & 6.4 & 1.00 & & 10 & 3.2 & 1.00 & \\
\hline Yes & 27 & 16.8 & $2.66(1.49-4.75)$ & 0.001 & 15 & 9.4 & $2.96(1.33-6.59)$ & 0.008 \\
\hline \multicolumn{9}{|l|}{ Condom use } \\
\hline Always & 12 & 14.6 & 1.00 & & 7 & 8.5 & 1.00 & \\
\hline Sometimes/Never & 36 & 9.3 & $0.63(0.32-1.21)$ & 0.172 & 18 & 4.6 & $0.54(0.22-1.30)$ & 0.171 \\
\hline Condom use in the last sexual & & & & & & & & \\
\hline intercourse & & & & & & & & \\
\hline No & 15 & 7.5 & 1.00 & & 8 & 4.7 & 1.00 & \\
\hline Yes & 32 & 11.9 & $1.57(0.85-2.90)$ & 0.148 & 17 & 6.3 & $1.56(0.67-3.62)$ & 0.295 \\
\hline
\end{tabular}

(continues) 
Table 2 (continued)

\begin{tabular}{|c|c|c|c|c|c|c|c|c|}
\hline \multirow[t]{2}{*}{ Variables } & \multicolumn{4}{|c|}{ Lifetime syphilis } & \multicolumn{4}{|c|}{ Active syphilis } \\
\hline & Positive & $\%$ & PR (95\%CI) & p-value * & Positive & $\%$ & PR (95\%CI) & p-value * \\
\hline \multicolumn{9}{|l|}{ Alcohol use before or during } \\
\hline \multicolumn{9}{|l|}{ sexual intercourse } \\
\hline Always & 8 & 15.7 & 1.00 & & 3 & 5.9 & 1.00 & \\
\hline Sometimes/Never & 41 & 9.6 & $0.78(0.52-1.18)$ & 0.252 & 23 & 5.4 & $0.67(0.38-1.18)$ & 0.170 \\
\hline \multicolumn{9}{|l|}{ Drug use before or during } \\
\hline \multicolumn{9}{|l|}{ sexual intercourse } \\
\hline Always & 17 & 8.9 & 1.00 & & 6 & 3.2 & 1.00 & \\
\hline Sometimes/Never & 32 & 11.1 & $1.25(0.89-1.76)$ & 0.190 & 20 & 7.0 & $1.48(0.92-2.37)$ & 0.101 \\
\hline \multirow{2}{*}{\multicolumn{9}{|c|}{$\begin{array}{l}\text { Sexual intercourse with people } \\
\text { with STIs }\end{array}$}} \\
\hline & & & & & & & & \\
\hline No & 40 & 10.1 & 1.00 & & 21 & 5.3 & 1.00 & \\
\hline Yes & 9 & 11.4 & $1.14(0.55-2.35)$ & 0.718 & 5 & 6.4 & $1.20(0.45-3.20)$ & 0.703 \\
\hline \multicolumn{9}{|l|}{ Sexual intercourse with sex } \\
\hline \multicolumn{9}{|l|}{ workers } \\
\hline No & 14 & 10.2 & 1.00 & & 5 & 3.7 & 1.00 & \\
\hline Yes & 35 & 10.2 & $0.99(0.53-1 . .84)$ & 0.985 & 21 & 6.1 & $1.67(0.62-4.42)$ & 0.303 \\
\hline \multirow{2}{*}{\multicolumn{9}{|c|}{$\begin{array}{l}\text { Sexual intercourse with illicit } \\
\text { drug users }\end{array}$}} \\
\hline & & & & & & & & \\
\hline No & 11 & 8.3 & 1.00 & & 5 & 3.8 & 1.00 & \\
\hline Yes & 38 & 11.1 & $1.35(0.69-2.64)$ & 0.379 & 21 & 6.2 & $1.64(0.61-4.35)$ & 0.318 \\
\hline \multicolumn{9}{|l|}{ Homosexual sexual intercourse } \\
\hline No & 32 & 9.5 & 1.00 & & 16 & 4.8 & 1.00 & \\
\hline Yes & 17 & 11.8 & $1.24(0.69-2.24)$ & 0.466 & 10 & 7.0 & $1.46(0.66-3.22)$ & 0.344 \\
\hline $\begin{array}{l}\text { Number of sexual partners in } \\
\text { the last year }\end{array}$ & \multicolumn{2}{|c|}{$2.0(1.0-4.0)$} & $1.01(0.98-1.04)$ & 0.277 & \multicolumn{2}{|c|}{$3.5(1.25-10.0)$} & $1.02(0.99-1.1)$ & 0.122 \\
\hline
\end{tabular}

95\% Cl: 95\% confidence interval; PR: prevalence ratio; STI: sexually transmitted infection.

Note: quantitative variables presented as medians and interquartile range (IQR).

* Wald chi-square test;

** PR calculated for every 30 days of stay on the street.

Table 3

Multiple regression of factors associated with lifetime syphilis in homeless men in Central Brazil.

\begin{tabular}{lcc}
\hline Variables & Adjusted PR * $\mathbf{9 5 \% C I )}$ & p-value ** \\
\hline Age (years) & $1.02(0.99-1.06)$ & 0.114 \\
Education (years) & $0.89(0.82-0.96)$ & $\mathbf{0 . 0 0 5}$ \\
Number of sexual partners & $1.01(0.99-1.03)$ & 0.248 \\
Condom use & $0.64(0.32-1.25)$ & 0.197 \\
History of genital ulcer & $2.59(1.43-4.72)$ & $\mathbf{0 . 0 0 2}$ \\
STI history & $1.97(1.02-3.79)$ & $\mathbf{0 . 0 4 2}$ \\
Previous hemotransfusion & $1.73(0.86-3.45)$ & 0.119 \\
Drug use before and/or during sexual intercourse & $1.60(1.06-2.41)$ & $\mathbf{0 . 0 2 2}$ \\
Alcohol use & $0.50(0.27-1.25)$ & 0.198 \\
\hline
\end{tabular}

95\%Cl: 95\% confidence interval; PR: prevalence ratio; STI: sexually transmitted infection.

* Adjusted for all variables with $p$-value $<0.20$ in the bivariate analysis;

** Wald chi-square test. 
Table 4

Multiple regression of factors associated with active syphilis in homeless men in Central Brazil.

\begin{tabular}{lcc}
\hline Variables & Adjusted PR * (95\%Cl) & p-value ** \\
\hline Age (years) & $1.02(0.97-1.07)$ & 0.412 \\
Education (years) & $1.05(0.94-1.16)$ & 0.335 \\
Number of sexual partners & $1.02(1.01-1.05)$ & $\mathbf{0 . 0 4 4}$ \\
Condom use & $0.52(0.18-1.44)$ & 0.210 \\
History of genital ulcer & $2.69(1.17-6.17)$ & $\mathbf{0 . 0 1 9}$ \\
STI history & $1.74(1.08-6.94)$ & $\mathbf{0 . 0 3 3}$ \\
Alcohol use before and/or during sexual intercourse & $0.79(0.47-1.31)$ & 0.372 \\
Drug use before and/or during sexual intercourse & $1.42(0.68-2.96)$ & 0.337 \\
Alcohol use & $0.47(0.19-1.19)$ & 0.113 \\
Crack use & $2.10(0.51-8.70)$ & 0.303
\end{tabular}

95\% Cl: 95\% confidence interval; PR: prevalence ratio; STI: sexually transmitted infection.

* Adjusted for all variables with $p$-value $<0.20$ in the bivariate analysis;

** Wald chi-square test.

alcohol consumption. There is a strong relationship between the use of alcohol and/or illicit drugs and STIs 25,38. Consumption of alcohol and illicit drugs lowers the perception of risk, reduces the user's ability to convince their partner to use a condom, and induces other risk behaviors (eg., sex for money and/or drugs and number of sexual partners), increasing the risk of acquiring syphilis and other STIs 39,40 . In this context, strengthening harm reduction strategies could contribute to reduce the burden of syphilis in homeless men 12 .

Approximately one-third of the homeless men reported a history of medical diagnosis of STIs, and $15.4 \%$ reported a history of genital ulcer. These variables were predictors of exposure to and active syphilis. The presence of STIs, especially ulcerative infections, increases the chance of transmission and acquisition of HIV 18. Ulcerative lesions facilitate the virus' access to cells under the epithelial surface and contact with blood, increasing the likelihood of systemic HIV infection ${ }^{41}$. It is estimated that the risk of HIV infection through sexual intercourse is increased 3-5 times in individuals infected with $T$. pallidum 42 .

This study has some limitations. The cross-sectional nature of the study design does not allow the establishment of a cause and effect relationship between syphilis and the variables investigated 33 . Longitudinal studies should be implemented to verify the risk or protective factors associated with syphilis in homeless men. The non-probabilistic sample used in the investigation and the inclusion of individuals attending therapeutic communities limits the generalization of the results to the population of homeless men from other localities in Brazil 29. Individuals treated in therapeutic communities may have different risk behaviors when compared to men with no link to these services 43 . However, the sociodemographic characteristics of the study participants were similar to other studies conducted in Brazil 12,22,29. Data related to risk factors were self-reported, liable to memory and response bias, especially due to the nature of the interview (face-to-face). Finally, potential false negative results due to the effect of prozone in the VDRL test are considered, and the positive results in the treponemal and non-treponemal tests may not necessarily indicate active syphilis, as there are possibilities of false-positive reactions. Despite the limitations, the results of this study add important information on the epidemiology of syphilis in homeless men in Brazil, indicating the need to control this infection and for educational actions focused on this population.

In conclusion, the results of this study show a high prevalence of syphilis among the homeless men investigated, confirming the vulnerability of this population to this infection. The participants reported multiple risk behaviors for STI, suggesting continued risk and potential dissemination of syphilis among their social networks. The high prevalence of syphilis and risk behaviors found in this study indicates the urgent need for the introduction of effective prevention measures. Despite the 
wide availability of diagnostic methods and simple treatment, syphilis still represents a major issue for homeless men in Central Brazil. The results of this study provide important data for the development of prevention strategies against syphilis and other STIs among homeless men, including the need for educational actions in services for homeless people, improvement of risk reduction programs, and availability of diagnostic tests, especially rapid tests and treatment of positive cases. Finally, further studies with homeless men in Brazil are needed to verify the true prevalence of the infection in other geographic locations.

\section{Contributors}

C. V. L. Barros contributed in the conception and design, acquisition of data, interpretation of results, drafting and approval of the final version for publication. H. Galdino Júnior participated in the Iinterpretation of results, drafting and approval of the final version for publication. G. Rezza participated on the interpretation of results, drafting, critical revision of the intellectual content and approval of the final version for publication. R. A. Guimarães contributed in the analysis of data, interpretation of results, drafting and approval of the final version for publication. P. M. Ferreira participated in the conception and design, acquisition of data, drafting and approval of the final version for publication. C. M. Souza, L. C. C. Guimarães and D. A. C. Barros contributed in the acquisition of data, drafting and approval of the final version for publication. S. M. Brunini contributed in the conception and design; acquisition of data; interpretation of results; drafting; critical revision of the intellectual content; approval of the final version for publication

\section{Acknowledgments}

The homeless men for participating in the study.

\section{References}

1. Stamm L. Syphilis: antibiotic treatment and resistance. Epidemiol Infect 2015; 143:156774.

2. Rose JE, Brauer LH, Behm FM, Cramblett M, Calkins K, Lawhon D. Psychopharmacological interactions between nicotine and ethanol. Nicotine Tob Res 2004; 6:133-44.

3. World Health Organization. Global incidence and prevalence of selected curable sexually transmitted infections - 2008. Geneva: World Health Organization; 2012.

4. Kenyon CR, Osbak K, Tsoumanis A. The global epidemiology of syphilis in the past century - a systematic review based on antenatal syphilis prevalence. PLoS Negl Trop Dis 2016; 10:e0004711.

5. World Health Organization. WHO guideline on syphilis screening and treatment for pregnant women. Geneva: World Health Organization; 2017.

6. Pan American Health Organization. Elimination of mother-to-child transmission of HIV and syphilis in the Americas. Update 2016. Washington DC: Pan American Health Organization; 2017. 
7. Cooper JM, Michelow IC, Wozniak PS, Sánchez PJ. In time: the persistence of congenital syphilis in Brazil. More progress needed! Rev Paul Pediatr 2016; 34:251-3.

8. Secretaria de Vigilância em Saúde, Ministério da Saúde. Boletim Epidemiológico Sífilis 2016; 47(35).

9. Ho EL, Lukehart SA. Syphilis: using modern approaches to understand an old disease. J Clin Invest 2011; 121:4584-92.

10. Talukdar A, Khandokar MR, Bandopadhyay SK, Detels R. Risk of HIV infection but not other sexually transmitted diseases is lower among homeless Muslim men in Kolkata. AIDS 2007; 21:2231-5.

11. Stoltey J, Cohen S. Syphilis transmission: a review of the current evidence. Sex Health 2015; 12:103-9.

12. Pinto VM, Tancredi MV, Alencar HDRD, Camolesi E, Holcman MM, Grecco JP, et al. Prevalência de sífilis e fatores associados a população em situação de rua de São Paulo, Brasil, com utilização de teste rápido. Rev Bras Epidemiol 2014; 17:341-54.

13. Grimley DM, Annang L, Lewis I, Smith RW, Aban I, Hooks T, et al. Sexually transmitted infections among urban shelter clients. Sex Transm Dis 2006; 33:666-9.

14. Vahdani P, Hosseini-Moghaddam S-M, Family A, Moheb-Dezfouli R. Prevalence of HBV, HCV, HIV, and syphilis among homeless subjects older than fifteen years in Tehran. Arch Iranian Med 2009; 12:483-7.

15. Fazel S, Geddes JR, Kushe M. The health of homeless people in high-income countries: descriptive epidemiology, health consequences, and clinical and policy recommendations. Lancet 2014; 384:1529-40.

16. Beijer U, Wolf A, Fazel S. Prevalence of tuberculosis, hepatitis $\mathrm{C}$ virus, and HIV in homeless people: a systematic review and meta-analysis. Lancet Infect Dis 2012; 12:859-70.

17. Rosenblum A, Nuttbrock L, McQuistion H, Magura S, Joseph H. Hepatitis C and substance use in a sample of homeless people in New York City. J Addict Dis 2001; 20:15-25.

18. Robertson MJ, Clark RA, Charlebois ED, Tulsky J, Long HL, Bangsberg DR, et al. HIV seroprevalence among homeless and marginally housed adults in San Francisco. Am J Public Health 2004; 94:1207-17.
19. Tyler K, Whitbeck L, Chen X, Johnson K. Sexual health of homeless youth: prevalence and correlates of sexually transmissible infections. Sex Health 2007; 4:57-61.

20. Zadeh AOT, Seyed Alinaghi S, Hassanzad FF, Hajizadeh M, Mohamadi S, Emamzadeh-Fard $S$, et al. Prevalence of HIV infection and the correlates among homeless in Tehran, Iran. Asian Pac J Trop Biomed 2014; 4:65-8.

21. López-Zetina J, Ford W, Weber M, Barna S, Woerhle T, Kerndt P, et al. Predictors of syphilis seroreactivity and prevalence of HIV among street recruited injection drug users in Los Angeles County, 1994-6. Sex Transm Infect 2000; 76:462-9.

22. Brito VOC, Parra D, Facchini R, Buchalla CM. Infecção pelo HIV, hepatites B e C e sífilis em moradores de rua, São Paulo. Rev Saúde Pública 2007; 41 Suppl 2:47-56.

23. West BT, McCabe SE. Incorporating complex sample design effects when only final survey weights are available. Stata J 2014; 12:718-25.

24. Fernandes FRP, Zanini PB, Rezende GR, Castro LS, Bandeira LM, Puga MA, et al. Syphilis infection, sexual practices and bisexual behaviour among men who have sex with men and transgender women: a cross-sectional study. Sex Transm Infect 2015; 91:142-9.

25. Coffin LS, Newberry A, Hagan H, Cleland CM, Jarlais DCD, Perlman DC. Syphilis in drug users in low and middle income countries. Int J Drug Policy 2010; 21:20-7.

26. Oztuna D, Elhan AH, Tuccar E. Investigation of four different normality tests in terms of type 1 error rate and power under different distributions. Turk J Med Sci 2006; 36:171-6.

27. Barros AJ, Hirakata VN. Alternatives for logistic regression in cross-sectional studies: an empirical comparison of models that directly estimate the prevalence ratio. BMC Med Res Methodol 2003; 3:21.

28. Coutinho LMS, Scazufca M, Menezes PR. Methods for estimating prevalence ratios in cross-sectional studies. Rev Saúde Pública 2008; 42:992-8. 
29. Grangeiro A, Holcman MM, Onaga ET, Alencar HDR, Placco ALN, Teixeira PR, et al. Prevalence and vulnerability of homeless people to HIV infection in São Paulo, Brazil. Rev Saúde Publica 2012; 46:674-84.

30. Programa Nacional de DST e Aids, Secretaria de Vigilância em Saúde, Ministério da Saúde. Prevalências e freqüências relativas de doenças sexualmente transmissíveis (DST) em populações selecionadas de seis capitais brasileiras, 2005. Brasília: Ministério da Saúde; 2008. (Série G. Estatística e Informação em Saúde).

31. Ribeiro D, Rezende E, Pinto V, Pereira G, Miranda A. Prevalence of and risk factors for syphilis in Brazilian armed forces conscripts. Sex Transm Infect 2012; 88:32-4.

32. Ruan Y, Luo F, Jia Y, Li X, Li Q, Liang H, et al. Risk factors for syphilis and prevalence of HIV, hepatitis $\mathrm{B}$ and $\mathrm{C}$ among men who have sex with men in Beijing, China: implications for HIV prevention. AIDS Behav 2009; 13:663-70.

33. Baptista CJ, Dourado I, Brignol S, Andrade TM, Bastos FI. Factors associated with syphilis seroreactivity among polydrug users in Northeast Brazil: a cross-sectional study using Respondent Driven Sampling. Int J Drug Policy 2017; 18:37-42.

34. Mayer KH, Wheeler DP, Bekker L-G, Grinsztejn B, Remien RH, Sandfort TGM, et al. Overcoming biological, behavioral and structural vulnerabilities: new directions in research to decrease HIV transmission in men who have sex with men. J Acquir Immune Defic Syndr 2013; 63 Suppl 2:S161-7.

35. Ogunmola OJ, Oladosu YO, Olamoyegun MA Relationship between socioeconomic status and HIV infection in a rural tertiary health center. HIV AIDS (Auckl) 2014; 6:61-7.

36. Solomon M, Smith M, Rio CD. Low educational level: a risk factor for sexually transmitted infections among commercial sex workers in Quito, Ecuador. Int J STD AIDS 2008; 19:264-7.
37. Machado DFGP, Martins T, Trevisol DJ, Silva RAV, Narciso-Schiavon JL, Trevisol FS, et al. Prevalence and factors associated with hepatitis B virus infection among senior citizens in a Southern Brazilian city. Hepat Mon 2013; 15:e7874.

38. Wu J, Huang J, Xu D, Lu C, Deng X, Zhou $\mathrm{X}$. Infection status and risk factors of HIV, $\mathrm{HBV}, \mathrm{HCV}$, and syphilis among drug users in Guangdong, China: a cross-sectional study. BMC Public Health 2010; 10:657.

39. Fisher JC, Bang H, Kapiga SH. The association between hiv infection and alcohol use: a systematic review and meta-analysis of African studies. Sex Transm Dis 2007; 34:856-63.

40. Ulibarri MD, Strathdee SA, Patterson TL. Sexual and drug use behaviors associated with HIV and Other sexually transmitted infections among female sex workers in the Mexico-U.S. border region. Curr Opin Psychiatry 2012; 23:215-20.

41. Ward H, Rönn M. The contribution of STIs to the sexual transmission of HIV. Curr Opin HIV AIDS 2010; 5:305-10.

42. Kassutto S, Sax P. HIV and syphilis coinfection: trends and interactions. AIDS Clin Care 2003; 15:9-15.

43. Logan JJ, Jolly AM, Blanford JI. The sociospatial network: risk and the role of place in the transmission of infectious diseases. PLoS One 2016; 11:e0146915. 


\section{Resumo}

O estudo teve como objetivo investigar a prevalência da sifilis e fatores associados em homens semteto no Centro-oeste do Brasil. A amostra nesse estudo transversal incluiu 481 indivíduos que frequentavam comunidades terapêuticas entre outubro e dezembro de 2015. Uma entrevista estruturada foi usada para coletar dados sociodemográficos e fatores de risco para sífilis. Foram realizados testes rápidos e VDRL para determinar a exposição à sifilis e a presença de sífilis ativa, respectivamente. $A$ análise de regressão de Poisson foi usada para verificar os fatores de risco associados aos desfechos investigados. Entre os participantes, 10,2\% foram reativos ao teste rápido e 5,4\% tinham sifilis ativa. Na análise de regressão múltipla, a escolaridade (razão de prevalência ajustada - RPA: 0,89; $p=0,005)$, história de úlcera genital (RPA: 2,59; $p=0,002)$, história de DST (RPA: 1,97; $p=0,042)$ e relações sexuais sob o efeito de drogas ( $R P A$ : $1,60 ; p=0,022)$ apareceram como fatores independentes associados à história pregressa de sífilis. Além disso, a história de úlcera genital (RPA: 2,19; $p=0,019)$, história de DST (RPA: 1,74; $p=$ $0,033)$ e número de parceiros sexuais no último ano (RPA: 1,02; $p=0,044)$ estiveram associados à sífilis ativa. A prevalência de sífilis em homens sem-teto era bastante elevada, confirmando a vulnerabilidade desse grupo à infecção. Os achados enfatizam a necessidade de intervenções educacionais, melhoria dos programas de redução de risco, disponibilidade de testes diagnósticos (sobretudo o teste rápido) e tratamento adequado.

Sífilis; Pessoas em Situação de Rua; Comportamento de Risco

\section{Resumen}

El objetivo de este estudio fue investigar la prevalencia y los factores asociados con la sifilis en hombres sin techo en el Centro-oeste de Brasil. Se trata de un estudio transversal, llevado a cabo con 481 personas que asistían a cuatro comunidades terapéuticas entre octubre y diciembre de 2015. La entrevista estructurada se realizó con el fin de recabar datos sociodemográficos y factores de riesgo para la sífilis. Se realizaron pruebas de diagnóstico rápido y serológicas para la sífilis (VDRL por sus siglas en inglés) para determinar la exposición a la sífilis y la presencia de sífilis activa, respectivamente. Se usó el análisis por regresión de Poisson para verificar los factores de riesgo asociados con los resultados investigados. Entre los participantes en el estudio, un 10,2\% fueron reactivos a las pruebas de diagnóstico rápido, y un 5,4\% tenían sífilis activa. En el análisis de regresión múltiple, la escolarización (la razón de prevalencia ajustada - APR: 0,89; $p=0,005)$, un historial de úlcera genital (APR: 2,59; $p=0,002)$, un historial de ETS (APR: 1,97; $p=0,042)$, e intercambios sexuales bajo los efectos de las drogas (APR: 1,60; $p=$ 0,022) fueron factores independientes asociados con la sífilis a lo largo de la vida. Asimismo, un historial de úlcera genital (APR: 2,19; $p=0,019$ ), un historial de ETS (APR: 1,74; $p=0$,033) y el número de parejas de índole sexual en el último año (APR: 1,02; $p=0,044$ ) estuvieron asociados con sifilis activa. La prevalencia de sifilis entre los hombres sin techo fue bastante alta, confirmando la vulnerabilidad de este grupo a la infección. Estos resultados enfatizan la necesidad de intervenciones educativas, así como una mejora en los programas de reducción del riesgo, disponibilidad de pruebas de diagnóstico, especialmente pruebas rápidas, $y$ tratamiento.

Sifilis; Personas Sin Hogar; Conducta de Riesgo
Submitted on 24/Feb/2017

Final version resubmitted on 22/Oct/2017

Approved on 31/Oct/2017 